\title{
Jak vedení výběrových základních škol prriděluje učitele do tříd?
}

\section{MONIKA KadRnOŽKOVÁ}

\begin{abstract}
Abstrakt: Český vzdělávací systém umožňuje rozrazovat žáky do škol a tř́d na základě jejich schopnosti a dosažených výsledkü. V současnosti je zaznamenán trend narüstajicího počtu základnich škol uplatňujicich dlouhodobou selekci žákư uvnitř školy. S rozŕazováním žákù do rüzných typư trúd úzce souvisi i téma pridèlováni učitelu. Tento text si klade za cil ovérit, zda vedeni trú výbèrových škol zámèrně priděluji učitele do tř́d a jaká kritéria je ovlivňuji. K naplnèni tohoto cíle byla určena jako výzkumná strategie deskriptivni prípadová studie a zakotvené teorie. Metodami sbèru dat byly zvoleny analyza pridèlováni učitelì do tríd v príslušných dokumentech (ŠVP, rozvrhy, výročni zprávy), hloubkové polostrukturované rozhovory s vedením a učiteli škol a analýza výsledkư srovnávacích testü žákư uvnitř škol. $Z$ výsledkù je patrné, že se vedení ve své volbě rúdi odlišnými kritérii, která odivvodñuje snahou co nejefektivněji vzdělávat žáky výbèrové dráhy. Ucitelé jsou pridèlováni do třid na základè volby vedeni, které vycházi z vlastnich kritérii kvalitního učitele - do výbèrových tríd jsou pridělování „kvalitnèjši“ učitelé, nebo je snahou vedeni do své školy prijimat pouze takové učitele, aby si již nemuseli vybirat a mohli pridèlovat do tríd učitele "strúdavým“ nebo "náhodným“ zpuisobem. V každém z prípadu ale bylo snahou vedení dostát ve výbèrové trúdě prohlubujicimu kurikulu s náročnějším obsahem a promyšleným didaktickým metodám. Vybrané školy se tak staly zajímavým príkladem prídělováni učitelù do tríd, což ovlivñuje nejen proces výuky, ale i samotné výsledky žákü.
\end{abstract}

Klíčová slova: pridělováni učitelù, diferenciace žákư, volba ředitele, základni škola, prípadová studie.

V Českém vzdělávacím prostředí se můžeme setkat $s$ rozřazováním žáků do odlišných studijních drah prostřednictvím výběrových škol či výběrových tříd uvnitř škol. Tento jev se nazývá diferenciace a lze ho dále rozlišit na diferenciaci vnější a vnitřní, přičemž u vnější diferenciace dochází $\mathrm{k}$ trvalému oddělení žáků do homogenních tříd po celou dobu výuky, při vnitřní diferenciaci jsou žáci naopak vyučováni odděleně $v$ heterogenních skupinách pouze na některé předměty po určitý časový úsek (Hallinan, 1994; Vališová \& Kasíková, 2007). V České republice je tradice výběrových a nevýběrových škol dlouhodobě zako-

\footnotetext{
${ }^{1}$ Výzkum byl podpořen Grantovou agenturou Univerzity Karlovy (projekt číslo 341615).
} 
řeněna $\mathrm{v}$ podobě víceletých gymnázií, která byla bez rozsáhlejší diskuse znovu obnovena po roce 1989. Kromě víceletých gymnázií se zde začala postupně uplatňovat také diferenciace žáků dle jejich schopností v podobě základních škol otevírajících výběrové třídy pro nadané žáky $\mathrm{v}$ různých oblastech (např́iklad jazykové, matematické či sportovní). Trend výběrových škol, které nejsou státem žádným způsobem kontrolovány ani limitovány, je neustále na vzestupu, přičemž vedení škol $\mathrm{k}$ rozhodnutí diferencovat žáky vedou různé motivy. Jedním z nich je prríprava žáků pro odlišnou vzdělávací dráhu vyžadující různou úroveň specifických znalostí (Schafer \& Olexa, 1971), snazší vzdělavatelnost žáků $s$ podobnými schopnostmi (Kilgore, 1991) nebo jednoduše snaha odlišit se od ostatních škol v konkurenčním boji o získání žáků.

Diferenciace $\mathrm{v}$ českém prostředí je tak velmi často uplatňována i přes zjištění mezinárodních výzkumů dlouhodobě poukazujících na fakt, že časná selekce zvyšuje rozdíly mezi výsledky žáků (Howie et al., 2017; Mullis, Martin \& Hooper, 2016). Žáci $v$ neakademicky zaměřené dráze často dosahují v souvislosti s nižším socioekonomickým zázemím rodiny, vlivem vrstevníků, nižším kladením studijních nároků a především také $\mathrm{v}$ souvislosti s kvalitou učitele horších výsledků než žáci umístění do akademicky zaměřené dráhy (Oakes, 1986; Hanushek, Kain \& Rivkin, 2005). V této souvislosti je velmi důležité zaměřit se na osobu učitele, který je klíčovým determinantem ovlivňujícím $\mathrm{z}$ velké části žáka $\mathrm{v}$ jeho školní úspěšnosti
(Cohen, Raudenbush \& Ball, 2003; Goe, 2007).

Mezi staršími studiemi lze nalézt šetření zabývající se kritérii ovlivňujícími vedení při rozhodování o přidělení učitelů do různých typů třríd (Heck \& Marcoulides, 1990; Carey, 1994), chybí však obdobné studie popisující aktuální situaci. Výzkumná šetření se $\mathrm{v}$ současné době zaměřují spíše než na efektivitu učitele na problematiku organizace žáků uvnitř tříd či škol (např́iklad dlouhodobě probíhající diskuse o efektivitě víceletých gymnázií). Samotnému tématu přidělování učitelů do různých typů tříd není věnována př́ilišná pozornost, přičemž právě kvalita přiděleného učitele může ovlivnit získané znalosti žáků (Gamoran, 1992; Lankford, Loeb \& Wyckoff, 2002). Tento fakt je podpořen i obecným míněním o fungování výběrových a nevýběrových škol a s nimi spojených „lepších“ a „horších “ učitelích. $Z$ výše popsaných důvodů nemáme bližší informace o naplnění či nenaplnění potřeb žáků prostřednictvím přidělení vhodných učitelů do tříd, lišících se svými schopnostmi, praxí, znalost$\mathrm{mi}$, osobnostní charakteristikou či prístupem $\mathrm{k}$ výuce.

Z popsaného stavu se jeví otázka přidělováni učitelů do tříd jako zásadní, protože s sebou přináší potenciální rozdíly mezi dosaženými výsledky žáků (Nystrand \& Gamoran, 1990; Ireson, Clark \& Hallam, 2002) a potenciální rozdíly ve spokojenosti učitelů se svým přidělením (Ball, 1981; Feng, 2010). Právě absence dat o způsobu, jakým se vedení škol rozhoduje při přidělování učitelů do tř́íd a jaký vliv jejich 
volba má na učitele a žáky, mě přivedla $\mathrm{k}$ tomuto tématu. Teoretický rámec jsem nasytila především studiemi vztahujícími se k oblasti diferenciace žáků, ze kterých lze vyčíst více informací o učitelích a jejich třídách (Rosenbaum, 1976; Goodlad, 1984; Oakes, 1986; Betts, Zau \& Rice, 2003; Goldhaber, Perry \& Anthony, 2004).

V následujícím textu popisuji šetření uskutečněné ve třech českých výběrových školách diferencujících žáky. Cílem bylo ověrit, zda vedení škol přiděluje učitele do tříd dle konkrétních kritérií, zjistit, z čeho tato kritéria vycházejí, a rozvinout teoretický a konceptuální rámec tématu.

\section{Přidělování uČitelư}

\section{DO DIFERENCOVANÝCH TŘíD}

Mezi kompetence ředitele, potažmo vedení školy patři přidělování učitelů do trríd, někteří ředitelé toto rozhodnutí delegují na své zástupce a ve výjimečných prrípadech i na samotné učitele (Carey, 1994). Přidělení učitelů se také odvíjí od typu vzdělávací dráhy (Loeb, Kalogrides \& Béteille, 2012), protože v nevýběrové dráze je obecně kladen důraz na základní dovednosti a výuka je založena spíše na memorování (Page, 1991), zatímco ve výběrové dráze je upřednostňováno učení se v souvislostech, žáci jsou podněcováni $\mathrm{k}$ samostatné práci a $\mathrm{k}$ diskusi (Rosenbaum, 1976). Podle Murphyho a Hallingera (1989) je rozdíl i v chování žáků, v nevýběrové dráze se učitel častěji zabývá sjednáváním pořádku, a proto mu nezbývá dostatečný prostor pro výuku předmětu (Gaziel, 1997). Z těchto důvodů Oakesová, Wells a Jones (1997) uvádějí, že je výuka ve výběrové dráze snazší, a někteří autoři se přiklánějí $\mathrm{k}$ názoru, že učitelé pracující se skupinou žáků s lepšími studijními předpoklady jsou spokojenější a úspěšnější ve své práci (Ball, 1981; Scafidi, Sjoquist \& Stinebrickner, 2007). $\mathrm{V}$ důsledku těchto okolností jsou školy $s$ horšími výsledky méně vyhledávané ze strany učitelů (Betts, Rueben \& Danenberg, 2000).

Přesto někteří autoři zastávají názor, že selekce žáků vytváří vhodné prostředí ke vzdělávání (Van Houtte, 2006), pozitivní dopady na všechny žáky ale dlouhodobě vyvracejí studie, které upozorňují na negativní vliv u žáků umístěných do nevýběrové dráhy (Nystrand \& Gamoran, 1990; Ireson et al., 2002). Kladný vliv je naopak zmiňován u žákủ výběrové dráhy profitujících z rychlejšího tempa výuky (Kulik \& Kulik, 1982).

Z výše uvedeného je patrné, že typ vzdělávací dráhy ovlivňuje i přístup učitele ke svěřeným žákům (Goodlad, 1984) a právě předsudky o schopnostech žáků mohou zkreslovat učitelovo očekávání (Ball, 1981).

\section{STAV ŘEŠENÉ PROBLEMATIKY}

V českých školách je uplatňována diferenciaci žáků již na prvním stupni i přesto, že selekce v raném věku může mít na žáky negativní vliv (Gamoran \& Bruch, 2010). Mnohdy je za tímto rozhodnutím snaha odlišit se a přivést více žáků do školy. At́ již se jedná o výuku ve kterémkoli typu 
třídy, je důležité sledovat práci učitele ovlivňující výsledky žáků a tím i kvalitu celé školy, ${ }^{2}$ proto je zde kladena otázka, kteř́ učitelé vyučují v různých typech tříd a jaké důsledky tato alokace s sebou prrináší? O přidělování učitelů do tříd nejsou v ČR vedeny záznamy, proto pro ucelenějši vhled do problematiky uvádím zjištění ze zahraničních studií zabývajících se rozhodnutím ředitelů, jakým způsobem přidělují učitele do tř́d (v závislosti na délce praxe, demografické poloze školy či složení žáků ve třídách).

Donaldson a Johnson (2011) uvádèjí, že pro ředitele jsou stěžejními kritérii $\mathrm{v}$ procesu alokace učitelů do tř́íd dlouhodobá praxe, vztah s žáky a demografická poloha školy, která ovlivňuje př́sun dobrých učitelů (Lankford et al., 2002). Podle Palána (2006) by učitelé měli odvádět kvalitní práci nezávisle na typu třídy, jsou ale všichni učitelé vhodní pro všechny skupiny žáků? Podle studie Dvořákové a Tvrzové (2010) kvalitní učitel může učit jakékoli žáky, záleží především na jeho osobnosti, autoritě a dovednostech. Studie blíže nespecifikuje, jaké vlastnosti by takový učitel měl mít, a odpověd' na tuto otázku není jednoznačná, protože ze zahraničních textů naopak plyne, že různým učitelům vyhovují odlišné skupiny žáků (Ireson et al., 2002; Goe, 2007).

Obdobné studie o přidělování učitelů do trríd na českých školách prozatím ne- vznikly, ale príbuznými tématy souvisejícími s diferenciací žáků se již čeští výzkumníci zabývají (Greger, 2004, 2006; Greger, Chvál, Walterová \& Černý, 2009; Straková \& Greger, 2013; Mareš, 2007).

\section{KONCEPT POZNATKOVÉ BÁZE UČITELSTVÍ}

Pro další práci $s$ daty jsem shledala za nezbytné vymezit, jakým způsobem budu charakterizovat kompetence učitele podstatné pro rozhodování vedení. Vzhledem $\mathrm{k}$ existenci mnoha definic obsahujících výčet potřebných kompetencí pro kvalitní výkon učitelské profese (O'Sullivan, 1999; Švec, 1998; Vašutová, 2001; Spilková, 2002; Kunter et al., 2013) jsem se přriklonila k využití přehledné Shulmanovy (1987) obecné koncepce poznatkové báze učitelství, která nepracuje $s$ pojmem kompetence, ale představuje $\mathrm{v}$ rámci sedmi kategorií znalosti a dovednosti učitele, jež v českém prostředí podrobněji představil Janík (2004).

Kategorie jsou charakterizovány jako znalosti vázané na obsah, které tvoří (1) znalosti vědních a jiných obsahů, (2) didaktické znalosti obsahu a (3) znalosti kurikula. ${ }^{3}$ Znalosti vědních obsahů se váží především $\mathrm{k}$ samotnému procesu $\mathrm{v}$ učitelově mysli, jedná se o komplex fakt a pojmů konkrétního oboru zahrnující pochopení všech vztahů vážících se jak

\footnotetext{
${ }^{2}$ Měŕítkem kvality školy se obecně staly výsledky žáků v mezinárodních srovnávacích testech (Cohen et al., 2003). Srovnávací testy ale nejsou vždy jednoznačným ukazatelem kvality, protože mnohdy nezahrnují individuální specifika žáků (Betts \& Shkolnik, 2000; Matějů \& Straková, 2003).

${ }^{3}$ Znalosti vědních a jiných obsahů, didaktické znalosti obsahu a znalosti kurikula vytvářejí ucelených koncept znalostí obsahu - content knowledge (Shulman, 1987).
} 
$\mathrm{k}$ oboru, tak $\mathrm{k}$ mezipředmětovým přesahům. Didaktické znalosti obsahu jsou zaměřeny na samotnou výuku předmětu, zaměřují se na předání znalostí různou formou a prostředky (interaktivní pomůcky, př́klady, demonstrace aj.). Znalosti kurikula vycházejí z pochopení jak oboru, tak mezipředmětových přesahů. Učitel je schopen uplatňovat média a didaktické prostředky, které vedou právě ke vzniku propojení mezi vyučovaným oborem a dalšími obory.

Zbývající čtyřri kategorie jsou (1) obecné pedagogické znalosti týkající se strategie samotného řízení a organizace třídy,

(2) znalosti o žákovi a jeho charakteristikách, které jsou důležité pro pochopení fungování třídy a zajištění potřeb jednotlivých žáků v ní, (3) znalosti o kontextech vzdělávání, které se vztahují ke kultuře školy a ke komunitě žáků a rodičů, kteří školu navštěvují a (4) znalosti o cílech, smyslu a hodnotách vzdělávání, jejichž součástí je vědění o historických a filozofických základech vzdělávání (Shulman, 1986, 1987; Janík, 2004; Janík \& Slavík, 2007).

Pod touto poslední složkou Shulman (1987) rozlišuje čtyři podsložky týkající se (1) vzdělání v obsahu disciplíny - jedná se o znalost porozumění zprostředkované látky, (2) vzdělávací materiály a struktury - prostřednictvím kterých lze dojít ke stanoveným cílům organizovaného školního vzdělávání (testy, kurikulum, organizace učitelů), (3) formální pedagogické vzdělání - především literatura týkající se problematiky vyučování a procesu učení (zahrnuje např́klad i etické aspekty výuky) a (4) moudrost praxe vycházející z praxe a zkušeností jednotlivých učitelů (Janík, 2004). Každý učitel ovládá jednotlivé kategorie odlišnou mírou, což je způsobeno osobností, skladbou žáků, typem školy, kulturním prostředím a dalšími faktory (tamtéž). Znalosti, které vedení vyžaduje po učitelích do různých typů tříd, jsou $v$ tomto šetření kategorizovány podle poznatkové báze učitelství, $v$ př́padě že je již nelze kategorizovat podle poznatkové báze učitelství, jsou pro ně stanoveny speciální kategorie.

\section{Metodologie VÝZKUMU}

Pro popis výzkumného plánu je využit Maxwellův (2008) interaktivní model výzkumného designu, který zahrnuje jednotlivé fáze kvalitativního výzkumu ve vzájemných vztazích. Klíčovým bodem je definice výzkumných otázek, které se odvíjejí od teoretického rámce popsaného výše a věnujícího se tématu diferenciace žáků a přidělování učitelů do tříd. Výzkumné otázky korespondují s cílem výzkumu - zjistit kritéria přidělování učitelů do třríd, přičemž jsou použity odpovídající metody sběru dat tak, aby přispívaly $\mathrm{k}$ zajištění kvality celého výzkumu.

\section{CÍl VÝZKUMU A VÝZKUMNÉ OTÁZKY}

Vybrané případy vycházejí z rozsáhlejšího výzkumu, který byl uskutečněn v rámci disertační práce (Kadrnožková, 2019), jejímž cílem bylo prozkoumat fenomén přidělování učitelů do tříd, popsat 
kritéria přidělování učitelů ve vybraných výběrových základních školách (úroveň ISCED 1 a ISCED 2) a zjistit, zda rozhodnutí vedení škol odpovídá vnímání prìidělených učitelů. $\mathrm{V}$ tomto textu si kladu za cíl: představit tři různé modely procesu rozhodování vedení o přidělování učitelů do tříd ve výběrových základních školách, popsat vnímání přidělených učitelů do tř́d a oveřit, zda se názory vedení a učitelů o schopnostech žáků v různých typech trríd shodují s jejich výsledky ve srovnávacích testech škol (jedná se bud' o specifické srovnávací testy, které si školy tvoří samy, nebo školy pro srovnávání výběrových a nevýběrových tříd využívají testy Scio či Kalibro).

Jako výzkumný problém je identifikován proces přidělování učitelů do tříd vedením ve vybraných výběrových školách a $\mathrm{v}$ této souvislosti jsou definovány výzkumné otázky. Hlavní výzkumná otázka: Jakým zpiosobem vedeni výbèrových $Z \breve{S}$ rozhoduje o prídělováni učiteli do diferencovaných typư tríd? Výzkumná otázka je dále rozčleněna na pět specifických otázek: 1 . Jakou roli hraje zaměření škol a uplatňovaná diferenciace žáků ve volbě vedení škol? 2. Jaké důvody vedou vedení škol $\mathrm{k}$ přidělování odlišných učitelů do diferencovaných tříd? 3. Jaké společné faktory pronikají do volby vedení škol přidělujících učitele do diferencovaných tříd? 4. Jakým způsobem ovlivňují jednotlivé znalosti učitele volbu vedení škol? 5. Jak vnímají své přidělení učitelé?

\section{VYUŽITÍ PŘíPADOVÉ STUDIE \\ KE ZJIŠTĚNí STAVU PŘIDĚLOVÁNí UČITELŮ DO DIFERENCOVANÝCH Tř́ID}

Ke zjišš̌ní stavu přidělování učitelů do diferencovaných trríd byla zvolena výzkumná strategie prŕpadové studie, kterou Yin (2014) definuje jako strategii zkoumání určitého jevu, a zakotvená teorie, která dle Švaříčka a Šedové (2007)

Tab. 1. Šetření v rámci př́ípadové studie

\begin{tabular}{|l|l|}
\hline Zvolený design empirického výzkumu & kvalitativní \\
\hline Typ př́padové studie & deskriptivní vícečetná případová studie \\
\hline Téma výzkumu & $\begin{array}{l}\text { studie výběrových škol vykazujících charakteristické } \\
\text { znaky }\end{array}$ \\
\hline Stanovení př́ipadu & vedení školy (ředitelé a další pověření pracovníci) \\
\hline Využité metody & analýza dokumentů, dotazování \\
\hline Sledované aspekty v šetření & kritéria přidělování učitelů do tříd \\
\hline Respondenti & vedení škol, učitelé \\
\hline Časová posloupnost terénního výzkumu & $\begin{array}{l}\text { ZŠ Barevná (zima 2017), ZŠ Otevřená (jaro 2018), } \\
\text { ZŠ Daleká (podzim 2018) }\end{array}$ \\
\hline Intepretace a prezentace př́padů & anonymní \\
\hline
\end{tabular}


představuje sadu systematických induktivních postupů pro vedení kvalitativního výzkumu zaměřeného na vytvářené nové teorie. Př́i stanovení případů bylo vycházeno z definice Stakea (2005) - případ jako entita zkoumající konkrétní osoby, organizace či události, bylo dodrženo vnitřní ohraničení prrípadu konkrétním místem a časem (Miovský, 2006) a využita vícečetná př́padová studie (konkrétně tř́i prrípady).

$Z$ těchto důvodů byly ústředním tématem studie zvoleny základní školy se shodnými charakteristickými rysy (diferenciace žáků, velikost škol, paralelní třídy, dostatek personálního zabezpečení, souhlas $\mathrm{k}$ výzkumu) a př́padem označeno vedení škol, které tvoří ředitelé a další pověření pracovníci rozhodující o přidělování učitelů do tříd. Výběr př́padů byl záměrný, uskutečněný $\mathrm{v}$ rámci kriteriálního vzorkování (Patton, 2002), pro získání škol diferencujících žáky do tříd byly uplatněny dvě základní metody: 1. metoda záměrného výběru - ZŠ Barevná a 2. metoda sněhové koule - ZŠ Otevřená a ZŠ Daleká (Glaser \& Strauss, 1967).

ZŠ Barevnou, která je zaměřena na rozšířenou výuku matematiky a přírodovědných předmětů, vede ředitelka (dále jen „ředitelka ŠB“), která si ponechala ve své kompetenci přidělování učitelů do tř́íd ještě z doby, kdy byla zástupkyní ředitele, přičemž na škole působí již přes 25 let. $\mathrm{V}$ ZŠ Otevřené rozhoduje o přidělování učitelů do tříd ředitel (dále jen „ředitel ŠO“). Škola prošla v nedávné době sloučením (pokyn zřizovatele) dvou výběrových škol (matematické a jazyko- vé), čímž bylo ovlivněno i rozhodování ředitele ŠO působícího přes deset let ve funkci ředitele jazykové školy. V Z ZS Daleká, která je orientovaná na rozšířenou výuku jazyků, ředitel (dále jen „ředitel ŠD“) působí teprve dva roky, príičemž dřive býval ředitelem na střední škole. Jakožto „nový“ ředitel má sice poslední slovo při přidělování učitelů do tříd, ale opírá se o názor zástupce a garantů jednotlivých předmětů. ZŠ Barevná a ZŠ Otevřená jsou školy nacházející se v hlavním městě, ZŠ Daleká leží ve městě do 30000 obyvatel.

\section{METODY SBĚRU DAT}

Sběr dat probíhal $\mathrm{v}$ několika fázích (ZŠ Barevná - zima 2017, ZŠ Otevřená - jaro 2018, ZŠ Daleká - podzim 2018) a byl uskutečněn prostřednictvím několika metod sestávajících (1) z analýzy uplatňované diferenciace zkoumaných škol, (2) $\mathrm{z}$ analýzy rozvrhů $\mathrm{v}$ rámci přidělování učitelů do tř́d, (3) z analýzy dokumentů (školní vzdělávací programy, výroční zprávy, zprávy České školní inspekce a případné autoevaluace škol), (4) z hloubkových polostrukturovaných individuálních rozhovorů $s$ vedením (ředitelé, zástupci), (5) z hloubkových polostrukturovaných rozhovorů $s$ učiteli výběrových i nevýběrových trríd a (6) z kvalitativní analýzy výsledků vlastních srovnávacích testů jednotlivých škol mezi výběrovými a nevýběrovými trrídami (vlastní testy, Scio nebo Kalibro).

Při sběru dat došlo ke kombinaci několika metod tak, aby byla zajišstěna 
Tab. 2. Respondenti, se kterými byly uskutečněny rozhovory

\begin{tabular}{|l|l|}
\hline Škola Barevná & $\begin{array}{l}\text { ředitelka ŠB, učitelka fyziky (výběrové třídy), učitelka chemie } \\
\text { (výběrové i nevýběrové třídy), učitelka matematiky (výběrové třídy) }\end{array}$ \\
\hline Škola Otevřená & $\begin{array}{l}\text { ředitel ŠO, učitel matematiky (výběrové třídy), učitelka anglického jazyka } \\
\text { (výběrové i nevýběrové tř́idy), učitelka německého jazyka } \\
\text { (výběrové i nevýběrové třídy) }\end{array}$ \\
\hline Škola Daleká & $\begin{array}{l}\text { ředitel ŠD, zástupce ŠD (nevýběrové třídy), učitelka anglického jazyka } \\
\text { (výběrové i nevýběrové třídy), učitelka německého jazyka (výběrové třídy) }\end{array}$ \\
\hline
\end{tabular}

metodologická triangulace. ${ }^{4}$ Pro zachování autenticity sběru dat byly zvukové nahrávky rozhovorů 5 doslovně přepsány dle transkripční konvence Leixové (2006) a všechny dokumenty řádně anonymizovány. Pro otevřené, axiální a selektivní kódování, ${ }^{6}$ kategorizaci a konceptualizaci dat byl použit softwarový program pro kvalitativní analýzu dat MAXQDA 2018. Pro dosažení spojení mezi kategoriemi a subkategoriemi byl v rámci axiálního kódování využit paradigmatický model, který se komplexně zabývá výzkumným problémem a zahrnuje kontext jevu, prríčinné podmínky, faktory ovlivňující zkoumaný jev, strategii řešeného jevu a důsledky vycházející ze strategie jednání (Šed’ová, 2005).

Po příslušném kódování dat následovala analýza a interpretace jednotlivých př́padů za využití deskriptivního př́stupu. Aby bylo dosaženo komparace jednotlivých př́padů mezi sebou a došlo k zajištění prozkoumání jejich podobností a odlišností, byla využita technika cross-case analýzy (Yin, 2014). Analýza dat proběhla $\mathrm{v}$ souladu $s$ navrženými metodami Pattona (1990): (1) identifikace, roztřídění a strukturace získaných dat, (2) kódování dat, vytvoření celků, (3) hledání vzájemných vztahů a (4) porovnání nových zjištění ze všech zdrojů dat.

\section{KONTEXT ŠKOL}

V ŽS Barevná je uskutečňována již přes 30 let diferenciace žáků od šestého ročníku do tříd $s$ rozšířenou výukou matematiky a př́rodovědných předmětů (dále jen „třídy s RVM“). Žáci do této trrídy konají výběrové řízení v pátém ročníku. Celkem jsou každoročně otevírány čtyři třídy, z čehož je jedna třída s RVM. Kromě diferenciace žáků do tř́íd s RVM je

\footnotetext{
${ }^{4}$ Metodologická triangulace byla zajištěna pomocí kombinace různých datových zdrojů (ŠVP, rozvrhy učitelů, výroční zprávy, kontrolní zprávy činnosti škol), sběru dat od různých skupin osob (ředitelé a učitelé škol) a ověření výsledků žáků ze srovnávacích testů škol.

${ }^{5}$ Rozhovory s učiteli trvaly cca 30 minut a rozhovory s řediteli či zástupci trvaly hodinu a půl.

${ }^{6}$ Švaříček a Šed’ová (2007) doporučují započít interpretaci dat otevřeným kódováním, na které navazují propracovanější analytické techniky - axiální a selektivní kódování vycházející z postupů zakotvené teorie.

${ }^{7} \mathrm{~V}$ každém ročníku od šesté třídy jsou paralelně tři nevýběrové tř́dy a jedna třída s RVM.
} 
zde také uplatňována od šestého ročníku selekce žáků do skupin podle jejich schopností v anglickém jazyce. ${ }^{8}$

ZŠ Otevřená je původně zaměrena pouze na rozšířenou výuku jazyků (vznikla již po revoluci), ale $\mathrm{v}$ nedávné době změnila svůj koncepční záměr, když došlo ze strany zřizovatele $\mathrm{k}$ jejímu sloučení s výběrovou školou zaměřenou na matematiku. V ZŠ Otevřená jsou otevírány celkem čtyři tř́ídy, z čehož diferenciace je zde uplatňována od třetího ročníku ve dvou trrídách jazykových, v jedné trrídě matematické a jedna trrída je ponechána bez specifického zaměření.

ZŠ Daleká je školou s dlouhodobou tradicí jazykového a hudebního zaměření zaměření žáků. Aktuálně jsou na prvním stupni otevírány čtyři třídy v každém ročníku, z čehož jedna třída je $s$ rozširrénou výukou cizích jazyků. Od diferenciace žáků do hudební třídy se již pro nevelký zájem upustilo, ale žáci si stále mohou vybrat předmět hra na hudební nástroj v rámci disponibilních hodin.

Všechny tři ZŠ využívají při diferenciaci žáků tzv. separační model (Dupriez, Dumaye \& Vause, 2008), který vychází z brzké diferenciace žáků a jejich odloučení od sebe na všechny předměty po celou dobu studia. Jedná se tedy o vnější diferenciaci, o které se zmiňují zahraniční studie $\mathrm{v}$ souvislosti $s$ rozdílným získáním znalostí žáků (Ireson et al., 2002; Goldhaber et al., 2004).

\section{PříčINNÉ PODMÍNKY - DƯVODY VEDOUCÍ K PŘIDĚLOVÁNí \\ UČITELŮ DO TŘÍD}

Filozofie ZŠ Barevná je založena především na propagaci tradice tříd s RVM, ve kterých se vedení školy snaží úroveň výuky zkvalitnit především konkrétním výběrem učitelů: „... to jsou predevšim takoví odzkoušeni učitelé už dlouhodobè (...) uči treba i na vysoké skole a maji to zázemí naučit tyble dèti nèco navic" (ředitelka ŠB). Ředitelka tak potvrzuje názor Gamorana a Mareho (1989), kteří soudí, že znalosti jednotlivých učitelů se mohou lišit $\mathrm{v}$ závislosti na typu přidělené tř́idy.

Ředitel ŠO s dlouhodobou zkušeností ve vedoucí funkci na jazykové škole využil sloučení dvou výběrových škol na maximum: „... to sloučeni zvedlo zájem o matiku, který už postupně upadal, celkovè se sem hlásí ještè víc dètí, když jsme propojili jazyky a matematiku" (ředitel ŠO). Škola se nyní profiluje ve dvou zaměřeních s tím, že žáci v matematické větvi mají z disponibilních hodin navíc jazykovou výuku a naopak, čímž se zájem ze strany rodičů o školu ještě zvýšil.

Reditel ŠD působí na ZŠ Daleká teprve druhým rokem, proto podotýká, že přišel do již zaběhnutého systému diferenciace žáků do jazykových tříd, ve kterém i nadále pokračuje: „... ta historie jazykové školy je prostě dána, takže $v$ tom pokračujeme“" (ředitel ŠD). Ředitel

\footnotetext{
${ }_{8}^{8}$ Žáci ve tř́ídách s RVM jsou dle schopností rozřazeni zvlášt do dvou skupin, na rozdíl od žáků ostatních nevýběrových tř́d, kteří jsou mezi sebou promícháni podle schopností v anglickém jazyku.
} 
ŠD si velmi dobře uvědomuje, že rodiče své žáky do školy umistují právě kvůli pověsti kvalitní jazykové př́pravy: „... škola prostě tu povèst má a dávaji sem dèti právěs vizí, že se ty jazyky dobře nauči" (ředitel ŠD).

\section{FAKTORY OVLIVŇUJící VEDENÍ ŠKOL PŘI PŘIDĚLENÍ UČITELU゚ DO TŘíD}

Faktory ovlivňující vedení škol byly stanoveny podle výsledků studie výzkumníků Clotfeltera, Ladda a Vigdora (2006) zabývajících se vlivem vnitřních a vnějších faktorů ovlivňujících rozhodování vedení škol při přijímání a přidělování učitelů do tříd tímto způsobem: zvyšování výkonu úspěšnějších žáků, zlepšení výsledků žáků se slabšími výsledky, přidělování učitelů do tříd formou náhodného výběru a přidělování učitelů do trríd formou střridání učitelů do výběrových a nevýběrových tříd.

Ředitelka ŠB je zaměřena především na zvyšování výkonu žáků ve třídách s RVM, proto vyčleňuje především prostor pro přidělování učitelů do tříd s RVM, což doplňuje výrokem: „My tém výběrovým trídám dáváme, asi to vyzní šilenè, výběrový, lepši učitele“ (ředitelka ŠB). Mimo tradici dobré úrovně tř́íd s RVM ji $\mathrm{k}$ tomuto rozhodnutí vede i prání rodičů: „... prícházejí dèti z rüzných škol do té matematické trídy, tak je lepší, když už je sem ti rodiče daji, aby to bylo opravdu zajištèno ze všech stran, jak ta oborovost, tak ten vztah $k$ nim" (ředitelka ŠB).
Ředitel ŠO shledává všechny učitele ve své škole kvalitními, proto mezi nimi již nedělá při přidělování do tříd rozdíl: „...v podstatè nedèlám žádný rozdíl (...) nehledim na to, kdo uči $v$ matematický a kdo ne!" Dle svého vyjádření ředitel ŠO inklinuje $\mathrm{k}$ prrístupu náhodného přidělování učitelů do tříd, což potvrzuje výrokem: "Já si prostě myslím, že všichni učitelé u nás jsou natolik dobři, že zvládnou ty trídy v̌̌echny! Už je tak prostě prijimáme, aby šli dát do všech trúid."

Ředitel ŠD vzhledem k teprve nedávnému nástupu do ZŠ Daleká přiznává, že vychází př̌edevším ze zaběhnutých tradic školy: „... prìstup $k$ prídělováni učiteli vedenim je už dán, takže $v$ tom pokračuji s drobnými úpravami" (ředitel ŠO). Zároveň klade důraz na vyvážené, spravedlivé přidělování učitelů do výběrových a nevýběrových tříd: „Míchá se to, neni tu jedna oblibená kolegyně, co by jela jenom výbèrová áčka, docházi $k$ výmènè učitelü“ (ředitel ŠD).

\section{STRATEGIE ROZHOdOVÁNí VEDENÍ PŘI PŘIDĚLOVÁNí UČITELŮ DO TŘÍD}

Strategický proces přidělování učitelů do tříd vedením škol je popsán nejprve v rámci kontextu koncepce poznatkové báze učitelství Shulmana (1987) a poté jsou zmíněny specifické atributy přidělování učitelů do tříd vedením, které nezapadají do koncepce poznatkové báze učitelství. Dále je uvedeno, jak učitelé vnímají své přidělení do tříd, a je provede- 
na komparace očekávaných výsledků žáků vedením a učiteli s výsledky srovnávacích testů, které školy uskutečňují ve třídách.

\section{Kritéria přidělování učitelů dle znalostí poznatkové báze učitelství}

Ředitelka ŠB se vyjádřila v kontextu trríd $s$ RVM ke znalostem vázaným na obsah. Do tř́íd $s$ RVM z hlediska znalosti obsahů upřednostňuje učitele, kteří jsou zároveň vysokoškolskými učiteli se schopností mezipředmětových přesahů: „... vysokoškolšti učitelé maji to oborové zázemi mnohem vétší, proto uči v matematických trídách; ti učitelé tam musi umèt učit vic predmétů dohromady" (ředitelka ŠB). Jako př́iklad saturace znalosti obsahů více předmětů uvádí aprobovanou učitelku matematiky vyučující předmět cvičení $\mathrm{z}$ matematiky, která vzhledem k dlouhodobému pobytu v Anglii ovládá také plynule anglický jazyk, proto vyučuje tento předmět $\mathrm{v}$ angličtině: „... je to postavené na zajimavých úlohách a ona na ně nepromluvi jinak než anglicky (...) je to opravdu dobrý a ty dèti to bavi a hroznè moc jim to $d a^{\prime \prime}$ (ředitelka ŠB). Podle ředitele ŠO mají znalosti vědních obsahů patřit $\mathrm{k}$ výbavě každého učitele: „... všichni učitelé tady umi ten svi̊j predmèt". Obdobný názor má i ředitel ŠD, který tvrdí, že: „Ve v̌sech trídách musí být $v$ ideálnim stavu ten kantor, kvalitni odborník a umět svưj predmèt" (ředitel ŠD).

V rámci didaktických znalostí obsahů ředitelka ŠB činí také rozdíl u nevýběrových tříd a tříd s RVM: „... ve trídách s RVM dělaji experimenty, objevuji, využivaji interaktivni prezentace, induktivní postupy, takže žáci sami pricházeji na princip, využivaji zajimavých úloh, aktivizuji žáky a uplatňují projektovou a skupinovou výuku." Didaktické požadavky na učitele trríd s RVM korespondují s tvrzením Burgesse (1983), tedy že na žáky výběrových tříd jsou kladeny vyšší nároky při výuce vztahující se $\mathrm{k}$ podněcování $\mathrm{k}$ různým formám samostatné nebo skupinové práce či k odlišným strategiím výuky. Ředitel ŠO spatřuje z didaktického hlediska problém u učitelů především $\mathrm{v}$ předání látky žákům a situaci přibližuje na př́íkladu výuky fyziky: „Mám dojem, že ty fyzikárky tady maji problém jim některé věci vysvětlit, aby to pochopili, hlavně u tèch nematematických!" Důvodem může být absence výuky předmětu fyzika na pedagogických fakultách, následkem čehož není dostatek aprobovaných fyzikářů, kteří by mohli předmět vyučovat: „... máme tu už jen učitelky, co jim je pres sedmdesát, tehdy ještě ta aprobace na ped'áku byla" (ředitel ŠO). Učitelé sami doplňují, že pocitují rozdíl z didaktického hlediska ve výuce výběrových a běžných tříd: „... tam je úplně jiná príprava i jiné učebnice, úplnè jiný styl (...) to je fakt rozdil, to se musi prizpiosobit $i$ rozloženi aktivit" (učitelka němčiny ŠO). „Tèm matematikárưm i jazykáriơm to prosté líp páli (...) lépe pochopi véci, tak si müžu dovolit jiné aktivity" (učitelka matematiky ŠO). Zástupce ŠD stejně jako ředitelka ŠB činí rozdíl mezi didaktickými požadavky na učitele výběrových a nevýběrových tříd: „Aby v těch výběrových modernè a věcně učil, využival aktivity s rüznými 
technickými pomůckami, nepoužival jen frontálni vyučováni, ale aby to bylo zábavnou formou, prosté takové ty moderni prvky, oni to ty dèti i vyžaduji!" (zástupce ŠD).

Z odpovědí vyplývá, že žákům navštěvujícím výběrové třídy se dostává odlišných výukových metod, které souvisejí $s$ předpokladem, že tito žáci chápou látku rychleji. Dále některým učitelům činí problém z didaktického hlediska vysvětlit látku žákům, a to především v předmětu fyzika. Ředitel ŠO si tento problém vysvětluje absencí aprobace předmětu fyzika na pedagogických fakultách, učitelé fyziky z odborných fakult podle jeho názoru postrádají didaktické schopnosti látku žákům předat.

Ředitelka ŠB klade jiné nároky na uplatňované kurikulum dle typu třídy: „...v v matematické trúdè jsou víc do hloubky, maji náročnějši Š $V P$, zvládnou toho víc, ten učitel si to musi pripravit náročnèjši na v̌sech frontách" (ředitelka ŠB). Učitelé ŠB tento názor kvitují: „... je to těžšsi príprava na ně (...) toho učiva s nimi proberu vic, jsou zvidavejjši a chytřejší" (učitelka chemie ŠB). Dosažené kurikulum ve třídách $s$ RVM poté ředitelka ŠB ověřuje pomocí vlastních srovnávacích testů, které nejsou zaměreny pouze na matematiku a př́rodovědné předměty, ale i na anglický a český jazyk: „... chceme, aby mèli žáci výsledky srovnatelné s viceletým gymnáziem" (ředitelka ŠB). Ředitel ŠO uvádí, že matematické skupiny a jazykové třídy mají $\mathrm{v}$ rozšiřujících předmětech prohloubené ŠVP: „Maji vic hodin matematiky nebo jazykư a vlastně prekračuji ten rámec $R V P$, takže ti učitelé museji být prippraveni na náročnějši výuku“ (ředitel ŠO), proto je zde i po učitelích vyžadováno přizpůsobit kurikulum probíraného předmětu nárokům žáků výběrové třídy: „... maji větši zájem, tak samozrejejě se dá s nimi postupovat rychleji, vic toho probrat (...) zvládne se větši množstvi učiva a mưžu jít třeba do hloubky, že řešime těžké úlohy" (učitelka matematiky ŠO); „... jsou chytřejši, tam dávám vyšši nároky" (učitelka anglického jazyka ŠO). Zároveň také učitelé uplatňují ve výběrových třídách znalosti mezipředmětových přesahů: „... jazykovi žáci maji vètš́ zásobu cizich slov třeba z umèni nebo $z$ technologii. Tak tam se jim to snažim propojovat" (učitelka anglického jazyka ŠO). O propojení jazykové výbavy a technologií v rámci mezipředmětových vztahů se snaží i ředitel ŠD: „... aby ten jazykár těch výbèrových tríd ovládal výpočetni techniku a zapojil ji do výuky, aby z toho mèli nèco navic, jako že pracuji na počitači $v$ anglickém jazyce" (ředitel ŠD). Lze tedy usuzovat, že žáci výběrových tříd povětšinou čerpají z prohlubujícího kurikula ve všech předmětech bez ohledu na fakt, zda se jedná o předmět $s$ rozšířenou výukou, či nikoli.

Obecné pedagogické znalosti jsou zapotřebí podle ředitelky ŠB ke zvládnutí kázně především v nevýběrových třídách: „... jako ti nevýbèroví víc zlobi“ (ředitelka ŠB), což potvrzuje i učitelka matematiky: „... víc zlobi déti v nevýbèrové trúdě, jsou tam spiš problémovi žáci" (učitelka matematiky ŠB). Ředitelka ŠB ale stejně jako ředitel ŠO při přidělování učitelů do tříd nedělá rozdíly $\mathrm{v}$ kontextu tříd $\mathrm{s}$ horší kázní: „... učitelé museji zvládnout v̌̌echny 
žáky“ (ředitelka ŠB); „...nedělám rozdily obecnè, musi si poradit ve vesech trídách" (ředitel ŠO). Učitelé ŠO potvrdili stejně jako učitelé ŠB rozdíl v chování žáků výběrových a nevýběrových tříd: „... ty výběrové jsou klidnějši a pracovitějši" (učitelka matematiky ŠO); „tam u těch nevýbérových je ta kázeñ náročnèjsí, jako vic se tam tím musim zabývat" (učitelka německého jazyka ŠO). Ředitel ŠD jako jediný zmínil, že mezi učiteli činí rozdíl $\mathrm{v}$ př́padě zvládnutí organizace třídy: „.. v té výběrové musí být vétši viidce, protože ty děti jsou chytřejši, klidnějš́, ale jejich spory jsou skrytějǔš, takže kantor musí být víc vnimavý a vidèt ty zá-

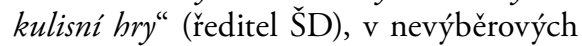
tř́iách je naopak nutné, aby si učitel byl schopen zjednat pořádek a klid ve tř́dè: „... tam musi být učitel, co je slyšet, co ty dèti zklidní, protože dèlají binec (...) to chce toho kantora razantního, který je umi rázně zkrotit" (ředitel ŠD). Učitelé vnímají rozhodnutí ředitele obdobně: „... učitel musí dát ve výbérové dohromady kolektiv, který tam je nic moc" (učitelka anglického jazyka S̆D); „... ty výbèrové dèti hưr komunikuji a nechtěji moc pracovat spolu" (učitelka německého jazyka ŠD).

Ředitelka ŠB klade důraz na učitelovy znalosti o žákovi především ve třídách s RVM: „... učitelé museji zvládnout individuálni prístup $k$ tèmble žákưm, proto tam vybirám ty empatické, to je cistě na mém pocitu“ (ředitelka ŠB). Učitelé doplňují, v čem spočívá individuální přístup $\mathrm{k}$ výběrovým žákům: „... nekomunikuji moc s učitelem, musi na to být ten člověk pripravený " (učitelka matematiky ŠB); „... nepracuji moc ve skupinè, jsou sólisti, tak $k$ nim musim $i$ pristupovat" (učitelka chemie ŠB). Ředitel ŠO se explicitně nevyjádřil $\mathrm{k}$ učitelovým znalostem o žákovi, naopak se ale vyjádřili učitelé ve vztahu $\mathrm{k}$ rozdílům mezi žáky výběrových a nevýběrových tříd: „... ta dynamika je jiná, jazykárí jsou vétši bohémové, jsou víc kreativni, maji rádi hry, matematici jdou na výkon, takže oni chtěji ten systém hlavně, pak ty nevýbèrové dèti jsou takové ménè motivované (učitelka anglického jazyka ŠO ). Ředitel ŠD stejně jako ředitelka ŠB klade důraz na znalosti o žácích u učitelů výběrových tříd: „... klademe dưraz, aby znal ty żáky, protože v těch trúdách nebývá dobrý kolektiv, jsou tam rváci s ostrými lokty, jsou to většinou už osobnosti, co chtěji někam jit" (ředitel ŠD). Ředitel ŠD zdůraznil také roli třídního učitele výběrových tříd: „... oni jsou ti trídni učitelé dưležití, aby ten kolektiv $v$ tý výberrový stmelovali, aby s tèmi dětmi mluvili, aby ten trídni odhalil utlacováni někoho, tak to musi ten učitel vnimat a pozorovat a sledovat" (ředitel ŠD). Po učitelích výběrových tříd je tedy vyžadována nejen oborová zdatnost, ale také pedagogicko-psychologická zdatnost pro vnímání potřeb svěřených žákủ.

Znalosti o kontextech vzdělávání vyžaduje ředitelka ŠB po učitelích v rámci udržení tradiční profilace školy: „... učitelé védí, že ty matematické trídy jsou nèco extra, když sem rodiče kvůli tomu dávaji dèti, tak aby $k$ tomu tak pristupovali “ (ředitelka ŠB). Učitelé vnímají zaměření školy obdobně: „... jsme trochu výkonnostně zamérená škola a chceme výsledky" (učitelka matematiky ŠB). Ředitel ŠO vnímá důležitost sžití učitelů s filozofií 
školy také jako velmi důležitý aspekt jejího fungování: „... ti učitelé tady ví, že jedeme na výkon" (ředitel ŠO), přičemž učitelé jeho názor potvrzují: „My tu nejsme vůbec alternativni, naše rodiče nevyžadujou, abychom tu s nimi sedèli na koberci a házeli mičkem, to fakt ne" (učitelka matematiky ŠO); „Dneska je všude inkluze, ale tady jako nehrozi, je to prostě na výkon" (učitelka německého jazyka ŠO); „... spiš se zamérujeme na výsledky žáki, aby to bylo vidèt, že umí, $i$ v téch olympiádách a na soutěžich" (učitelka anglického jazyka ŠO). Vzhledem k tomu, že ředitel ŠD působí ve škole teprve dva roky, snaží se naopak on sžít s filozofií své školy: ,... škola je svým zpuisobem zaměrena na výkon, jsme jediná výbèrová ve mèstè a tu pověst má dobrou, tak ta výuka výbèrových tríd musi být kvalitni" (ředitel ŠD).

Kritérium délky praxe je pro ředitelku ŠB důležité a v tomto ohledu činí zásadní rozdíl mezi přidělováním učitelů do tříd s RVM a do nevýběrových tříd: „... u výbèrových maji opravdu, opravdu dlouhodobou praxi, tam začátečníky nedávám, musim ty učitele znát a védět, že uči dobre a umi si s nimi poradit" (ředitelka ŠB). Její názor koresponduje s tvrzením Hanuskaet al. (1998), že jsou učitelé bez dlouholeté praxe přidělováni do tříd se slabšími výsledky. Ředitel ŠO naopak $\mathrm{v}$ délce praxe problém nevidí a doplňuje, že se řídí svým vlastním úsudkem, a to již př̀i přiijímání učitelů: „Když je príijimáme, tak si otipuju, jestli na to bude mit nebo ne, ale že bych se tomu bez praxe bránil, to ne! (...) mnè začinající učitelé nevadí." Zároveň také spatřuje výhodu statusu fakultní školy: „... hrozně pomáhá, že jsme fakultní škola, když hledám učitele, tak si vytipujeme s pani zástupkyni studenty z praxe" (ředitel ŠO). Ředitel ŠD také přiděluje do výběrových tříd učitele $s$ krátkodobou praxí: „Mèli jsme tu adeptku, čerstvě po škole, to byl koncert na ukázkové hodinè, co všechno umèla, ta by k tèm výbèrovým hned mohla" (ředitel ŠD). Pozitivně vidí i návraty žáků, kteři vystudovali pedagogickou fakultu a ucházejí se nyní o místo učitele ve škole Daleká: „... je fajn, když sem jdou děti, které jsme si vychovali, protože ten náš prìstup budou respektovat a pokračovat v nèm (ředitel ŠD). Naopak, největší problém začínajících učitelù spatřuje ve sjednávání kázně ve třídě: „Noví kantoři moc tu kázeň nezvládají, ale jsou naopak nabití védomostmi ze školy" (ředitel ŠD).

\section{Specifická kritéria}

Ředitelka ŠB velmi pozitivně kvituje praxi přidělování druhostupňových učitelů na první stupeň (1) z důvodu snazšího přechodu žáků na druhý stupeň: „... hodně učitelì druhostupňových uči na proním stupni některé predmèty, je to pro ty dèti dobré, právě aby si zvykly na vic učiteli̊ najednou" a (2) z důvodu předpokládané kvality znalosti obsahu předmětu: „... angličtinári jsou na prvním stupni všichni druhostupňoví, raději je tam dávám, mám jistotu, že umi ten jazyk" (ředitelka ŠB). Anglický jazyk považuje ředitelka ŠB za prioritní, stejně jako výběrové předměty: „... je prostě důležitý, dneska se na to klade dirraz, $i$ ti rodiče to chtěji " (ředitelka ŠB). Naopak v jiných 
předmětech (např. výtvarná výchova) mohou být přiděleni neaprobovaní učitelé: „... tam to mưže dělat ten, co ho to bavi třeba" (ředitelka ŠB). Volba přidělení aprobovaného učitele do třídy tedy závisí i na aktuálních trendech společnosti a požadavcích rodičů. Ředitel ŠO stejně jako ředitelka ŠB přiděluje již na prvním stupni druhostupňové učitele do výběrových tř́id z důvodu zaručení kvality znalosti obsahu $\mathrm{v}$ případě výběrových předmětů (matematika a anglický jazyk): ,... prvostupňové učitelky ve výbèrových máme na anglický jazyk a matematiku jen v proní a druhé tř́dè, pak už tam dáváme ty druhostupñové, aby to mélo úroveñ " (ředitel ŠO). Ǩeditel ŠD uvažuje o přidělování druhostupňových učitelů $\mathrm{v}$ rámci jazyka obdobně jako ředitelka ŠB a ředitel ŠO: „... takble to máme nastavené, protože jsme vždy byli škola s rozšírenou výukou jazykü, takže máme prioritnè druhostupñové učitele angličtinárée pro všechny věkové skupiny, aby to bylo na úrovni“ (ředitel ŠD).

Dalším specifickým znakem je tradice přidělování opakujících se učitelů do výběrových tříd, kteři $\mathrm{v}$ nich působí třeba i přes 20 let: „... jsou odzkoušeni, ty úvazky tady máme z minulých let, tak je jenom povýsime" (ředitelka ŠB). Ředitel ŠO se v rozhovoru vyjádřil, že učitele může libovolně přidělovat do výběrových a nevýběrových tříd, protože si je jist jejich kvalitou, posléze ale vyplynulo, že je tomu tak pouze $\mathrm{v}$ prŕípadě učitelů původní jazykové školy. Učitele ze sloučené matematické školy ihned posoudit neuměl, proto jejich stávající prridělení do trríd ponechal dle zaběhnuté tradice: „... ty učitele jsem nechal $v$ tèch matematických trídách, jak byli, protože tam moc nebylo co vymýšlet, když jsem je neznal" (ředitel ŠO). Přesto však $\mathrm{v}$ jednom prípadě udělal výjimku, a to u učitele, který dostal šanci se nově začlenit do výuky matematické tř́ídy i přesto, že na integrované matematické škole učil nevýběrové třídy: „... tam šly učitelky $u \check{z}$ do dúchodu a on projevil zájem o ty výbérové skupiny, tak jsme to zkusili“" (ředitel ŠO). Učitel, který dostal šanci učit v matematických třídách, je velmi rád, protože mu změna umožnila se více zapojit a angažovat: „Mám tady to pole pisobnosti větši“ (učitel matematiky ŠO).

Aprobovanost také hraje roli při rozhodování o přidělení učitelů do tř́íd. Učitelka ŠB uvádí jako př́klad učitele IKT: „.. v nevýbèrové trídě je inženýr a nemá na to vzdèlání, uči takové ty základy (...) $v$ matematických, tam už se uči základy programování, tam už opravdu dáváme vystudovaného informatikáré " (ředitelka ŠB). Zde se také promítá fakt, že žáci nevýběrových třrid mají odlišné kurikulum v předmětu IKT, přičemž na žáky nevýběrových tříd nejsou kladeny tak vysoké nároky, což koresponduje s tvrzením Oakesové (1986), že u žáků výběrových tříd jsou očekávány lepši výsledky než už žáků tříd nevýběrových (což jde ruku v ruce $s$ odlišným kurikulem). Ředitel ŠO uvedl také případ, kdy přiděluje do tříd neaprobované učitele, jedná se též o předmět IKT: „Kdybych mél ajtáka, tak ho tam dám, ale ajtáka tady nemám! To je vèc, která se nedá zaplatit, samozrejmé, ajtáci berou úplně jiný penize" (ředitel ŠO). Ředitel ŠO tento problém řeší tím způsobem, že 
předmět IKT přiděluje především učitelům výtvarné výchovy a českého jazyku: „... ICT uči u nás hodně výtvarkári, kteři to uměji!', dělaji tam úpravy obrazũ a dělà se tam strùh videa a tyhlety věci (...) Pak to uči češtinárky, protože tam je psani všemi dese$t i$ “ (ředitel ŠO). Ředitel ŠD doplňuje, že u anglického jazyka a tzv. core předmětů9 přiděluje pouze aprobované učitele: , $V n a-$ prosté vétšinè v tèch hlavnich prédmètech se $v$ devadesáti deviti procentech snažime, aby to opravdu učili ti, co to zamèreni maji!" (ředitel ŠD). Naopak u vedlejších předmětů ředitel ŠD přiděluje i učitele bez požadované aprobace: „... třeba $v$ dějepise kolega nemá aprobaci dèjepis, má aprobaci občanskou výchovu, ale má $k$ tomu blizko a sám se v podstatě nabidl, že by ten dèjepis chtěl učit a má ho rád, tak proč ne (...) výtvarnou výchovu nebo nèjaké technické práce uči někdo, kdo má o to zájem nebo to je jeho koniček" (ředitel ŠD).

Specifickým úkazem pouze v ZŠ Barevná jsou tzv. rotující učitelé pátých a šestých ročníkü. Tento systém zavedla ředitelka ŠB jako opatření proti rozdílům fungování v procesu výuky na prvním stupni, kdy mají žáci prakticky pouze jednoho učitele, a na druhém stupni, kdy se začnou učitelé střrídat $\mathrm{v}$ každém předmětu: „... mèli by jednoho učitele od prvni do páté třidy a najednou se jim začnou na v̌sechny predmèty střidat. V té sestce to musi být strašná rána!" (ředitelka ŠB). Učitelé, kteří tak mají možnost učit jak na prvním nediferencovaném, tak na druhém dife- rencovaném stupni, doplňují: „,.. $k d y z ̌$ pak učim v té šestce ty nevýbèrové, tak tam chybi nèjaký tahoun, ti odejdou do té matematické trídy nebo na gymnázium. Zni to špatnè, ale pak ta trída má opravdu slabši nebo chabé výsledky, uči se mi tam pak hưr r" (učitelka fyziky ŠB). Její názor potvrzuje stanovisko Schwartze (1981), že učitelé nevýběrových tříd mohou být méně spokojeni s dosaženými výsledky u žáků, což může ovlivnit i jejich motivaci, př́pravu či celkovou spokojenost $\mathrm{v}$ profesi.

\section{VÝSLEDKY ŽÁKŮ VÝBĚROVÝCH A NEVÝBĚROVÝCH TŘíD \\ VE VLASTNIÍCH SROVNÁVACÍCH \\ TESTECH ZKOUMANÝCH ŠKOL}

Výsledky srovnávacích testů Kalibro šestých a devátých tříd ve škole Barevná ukázaly, že žáci tříd s RVM jsou ve všech sledovaných předmětech úspěšnější než žáci nevýběrových tř́d. Zajímavé je, že tř́idy $s$ RVM presahovaly $v$ některých předmětech (matematika a anglický jazyk) i průměrné výsledky žáků víceletých gymnázií ČR, což odpovídá snaze ředitelky ŠB vyrovnat se výsledkům víceletých gymnázií. Škola Otevřená pro srovnání výsledků žáků jednotlivých tříd také využila testy Kalibro ve třetích a šestých třídách. Testy potvrdily, že žáci jazykových tříd mají nejlepší výsledky $\mathrm{v}$ anglickém jazyce, za nimi se umístili žáci matematických tř́id a nejhůře dopadli žáci nevýbě-

\footnotetext{
${ }^{9}$ Core předměty jsou běžně chápány a označovány jako „hlavni“. Obvykle mezi ně patří matematika, český jazyk, cizí jazyk apod.
} 
rových tříd. $\mathrm{V}$ matematice byly $\mathrm{v}$ případě výběrových tříd výsledky opačné, nejlépe dopadly matematické trrídy, poté jazykové třídy a nejhưřre opět tř́ídy nevýběrové. Tento stav lze vysvětlit přidělováním druhostupňových učitelů $\mathrm{k}$ matematickým a jazykovým tř́dám již na prvním stupni a vysokou mírou motivace žáků výběrových tříd, kterou zdůrazňují v rozhovorech všichni učitelé školy Otevřená: „... ty dèti jsou v matematické namotivované $z$ domova, snaži se" (učitel matematiky ŠO); „... v nevýbèrových jsou dèti, které to berou jako dalši bohužel nutný zlo a ta motivace je tam velmi malá (...) vètšinou je velká drina do nich néco nahustit" (učitelka německého jazyka ŠO); „... ty spádové děti nejsou prostè úplnè namotivovanése učit" (učitelka anglického jazyka ŠO). Za nízkou motivovaností stojí podle učitelů převážně socioekonomické zázemí rodiny a motivace žáků $\mathrm{k}$ učení ze strany rodičů: "Je to dané $i$ socioekonomickým zázemím rodiny, ty běžné dětti nejsou tlačeny z rodiny na výkon" (učitel matematiky ŠO). Socioekonomické zázemí rodiny vnímají učitelé ŠO jako důležitý aspekt ovlivňující žáky při dosahování jejich úspěchů, což koresponduje $s$ výsledky mezinárodních šetření PISA (2012, 2016), která dlouhodobě upozorňují na zvyšující se rozdíly mezi žáky v závislosti na socioekonomickém zázemí rodiny. Škola Daleká pro porovnání dosažených výsledků žáků mezi výběrovými a nevýběrovými třídami využívá vlastních srovnávacích testů skládajících se z cizího jazyka a českého jazyka. Výsledky jazykových trríd dopadly $\mathrm{v}$ obou předmětech a ve všech testovaných ročnících (šestý, osmý a devátý) výrazněji lépe. Vyšší dosažené výsledky u žáků jazykových tříd odpovídají navýšené dotaci cizího jazyka od třetího ročníku. Zajímavé výsledky přinesly srovnávací testy $\mathrm{v}$ předmětu český jazyk v osmých ročnících, kdy jazyková tř́́da dosáhla lepších výsledků v úspěšnosti žáků až o $30 \%$. Český jazyk nepatří mezi předměty, ve kterých má jazyková třída navýšenou hodinovou dotaci. Lepší výsledek jazykové třídy ale koresponduje $s$ názorem ředitele ŠD a učitelů: ,... tam jsou ty lepši dětti, tak ve všech těch predmètech jedou vic do hloubky" (učitelka anglického jazyka ŠD); „Ty výbérové trídy jsou rychlejsí, stihne se tam víc práce a od toho se odviji, že se ty kompetence rozviji vic" (učitelka německého jazyka ŠD).

\section{DƯSLEDKY PŘIDĚLOVÁNí UČITELŮ DO TŘíD}

Učitelé vnímají rozdíl ve výuce žáků výběrových tříd: „... jsou zvidavější, vic se ptaji" (učitelka chemie ŠB); ,jsou mnohem rychlejši" (učitel matematiky ŠO); „věnuji tomu učeni vétši pozornost" (učitelka fyziky ŠB) a nevýběrových tříd: "ta motivace je tam nizká, nechtěji se moc učit" (učitelka německého jazyka ŠO); ,nezajimaji se tak ani neptaji" (učitelka anglického jazyka ŠD). Učitelé se také vyjádřili $\mathrm{k}$ předpokládaným schopnostem žáků: „... tam stači nahodit téma a užjim to běži $v$ hlavẹ̌!" (učitelka matematiky ŠB); „... jsou tam bystřejši děti!" (učitelka německého jazyka ŠD); „... tam můžu jit vice do hloubky" (učitelka anglického jazyka ŠD). Dotázaní učitelé automaticky očeká- 
vají u žáků výběrových tř́íd vyšší motivovanost a schopnost více se naučit a podle tohoto úsudku k žákům také přistupují. $\mathrm{V}$ tomto př́padě se tedy potvrzuje, že typ vzdělávací dráhy ovlivňuje i prístup samotných učitelů $\mathrm{k}$ žákům (Goodlad, 1984). Tento přístup s sebou přináší také odlišnou př́pravu učitelů do různých typů tříd: „... do těch výbèrových si pripravuji věci navic, tam jen učebnice nestačì" (učitel matematiky ŠO); „... musite tam por̀ád mit nějaké zajimavé věci, aby je to bavilo, nějaké těžšsi“ (učitelka anglického jazyka ŠD). Přidělování učitelů do tříd ovlivňuje $\mathrm{v}$ prrípadě zkoumaných škol výsledky žáků výběrových a nevýběrových tříd. Důsledkem toho také vysoký počet žáků odchází $\mathrm{z}$ výběrových tř́íd na víceletá gymnázia. Tento fakt však vnímají učitelé negativně: ,... po odchodu těch tahounů na gymnázia jsou ty výsledky žáki slabšı" (učitelka chemie ŠB); „.. pak už se tam uči trochu hůr̆, ti nejlepši odejdou" (učitelka anglického jazyka ŠD).

\section{DisKuSE}

Důvodů vedoucích $\mathrm{k}$ záměrnému přidělování učitelů do tříd je více, mezi ty hlavní patří snaha o zajištění co nejefektivnějšího vzdělávacího procesu podle typu uplatňované diferenciace, což koresponduje s názorem Hallinanové (1994). Vedení zkoumaných škol se rozhoduje na základě vnějších a vnitřních vlivů, přičemž jako nejpodstatnější se ukázalo $\mathrm{v}$ př́padě všech trrí zkoumaných škol zaměření na výkon žáků výběrových tř́íd. Všechny tř́i školy také vycházejí z dlouhodobé tradice vnější diferenciace žáků s důrazem na zajištění kvalitní výuky především výběrových tříd. Vedení ŠB přiděluje „ty lepší “ učitele do výběrových tříd: „My tèm výběrovým trúdám dáváme lepši učitele,

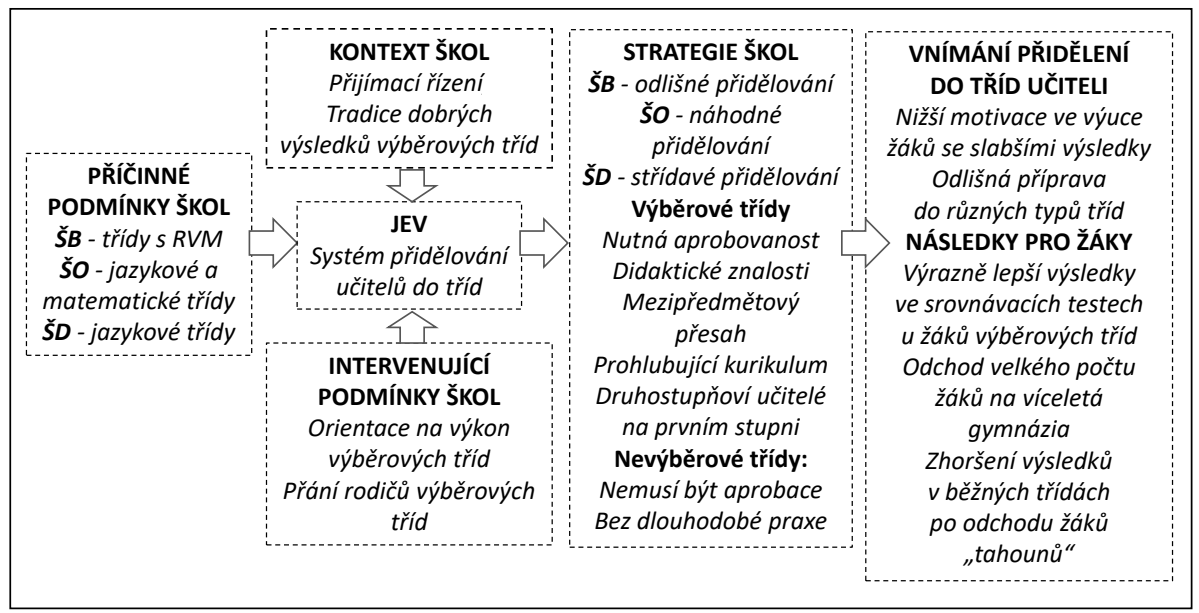

Obr. 1. Strategie přidělování učitelů do tříd vycházející z paradigmatického modelu 
co maji u žákư ty výsledky“ (ředitelka ŠB), čímž dochází $\mathrm{k}$ podpoře zvyšování nerovností mezi výběrovými a nevýběrovými tř́́dami (Oakes, 1986). Ředitel ŠO se snaží neupřednostňovat učitele, proto je přiděluje náhodným způsobem: ,... v podstatě nedèlám žádný rozdíl, v každém ročníku máme čtyrí trídy, tam se museji úvazky rozházet a pak s nimi logicky jou dál" (ředitel ŠO). Ředitel ŠD naopak přiděluje učitele do tříd stř́ídavě, tak aby každý učitel měl šanci učit ve výběrových i nevýběrových tř́dách, což koresponduje $s$ názorem Goodlada (1984), tedy že učitelé, kteří zažívají úspěch z dobrých výsledků žáků, jsou spokojenější ve své práci.

Společnými faktory, kterými se vedení všech tř̌i škol řídí při přidělování učitelů do tř́d, jsou dle Shumanovy (1987) koncepce poznatkové báze učitelství především znalosti vědních obsahů a znalosti kurikula. Prioritu vedení škol přikládá kvalitnímu oborovému zázemí učitelů, schopnosti mezipředmětového propojení a zkušenosti s prohlubujícím kurikulem ve výběrových třídách. Z hlediska didaktických znalostí vyžaduje vedení škol po učitelích nadstandardní didaktický přístup $\mathrm{k}$ žákům výběrových tříd: „... dèlaji experimenty, objevuji, uplatñuji projektovou a skupinovou výuku" (ředitelka ŠB); „... uplatňuji badatelské techniky, umi analyzovat, vytváret systematické koncepty a maji velké zkušenosti a znalosti ve využití rưzných metod" (ředitel ŠO). Obdobné výsledky zaznamenávají i autoři zahraničních studií, kteří si všímají extra pozornosti učitelů ve výběrové dráze při využívání kritického myšlení, samostatné práce či umění argumentace (Evertson, 1982; Page, 1991; Haycock, 1998).

Z hlediska obecných pedagogických znalostí přiděluje vedení škol do výběrových tříd učitele vykazující schopnost odhalení problematických vztahů mezi žáky: „... ty dèti jsou chytřejši a jejich spory skrytejjši, takže kantor musi být víc vnimavý a vidèt ty zákulisni hry" (ředitel ŠD). Do nevýběrových tříd naopak upřednostňují vlastnost zvládání a sjednávání pořádku ve třídě: „...v nevýbérové je kázen náročnějši, víc se tam tím musim zabývat a udržet pořádek" (ředitelka ŠB). Otázka délky praxe se ukázala prioritní pro ředitelku ŠB, která konstatuje: „... do těch výbérových dáváme ty, co maji opravdu dlouhodobou praxi, že jsou opravdu provéreneni" (ředitelka ŠB). Ředitelé ŠO a ŠD naopak přidělují do výběrových tříd jak učitele s dlouhodobou praxí, tak i začínající učitele. Ředitelé ŠO a ŠD tak nepotvrzují výsledky zahraničních studií, které uvádějí, že učitelé s krátkodobou praxí či bez praxe bývají umistováni pouze $\mathrm{k}$ žákům do nevýběrové dráhy (Betts e al., 2003; Feng, 2010).

Ke specifickým kritériím přidělování učitelů do trríd se ředitelé vyjádřili shodně v př́padě alokace druhostupňových učitelů do výběrových tříd na prvním stupni. Jako důvod uvedli zajištění znalosti obsahu. Stejně tak se všichni tři ředitelé shodli na nutnosti aprobovanosti u učitelů ve výběrových třídách. Dále ředitelé vyžadují aprobovanost $\mathrm{u}$ učitelů $\mathrm{v}$ prrípadě core předmětů, naopak $\mathrm{v}$ předmětech netýkajících se rozširirené výuky ředitelé považují za přirozené přidělit učitele, který aproba- 
ci nemá, ale $\mathrm{k}$ předmětu má osobní vztah, či si předmětem doplňuje úvazek. $\mathrm{V}$ zahraničních studiích se autoři explicitně nevyjadřují $\mathrm{k}$ přidělování učitelů do tříd na základě jejich aprobovanosti, ale setkávají se také s problematikou nedostatku kvalifikovaných učitelů, zvláště ve školách nacházejících se v lokalitách s dlouhodobě velmi špatnými výsledky žáků (Lankford et al., 2002).

Tradici dlouhodobého pridělování stejných učitelů do výběrových tříd upřednostňuje ředitelka ŠB, která spoléhá na jejich dlouholeté zkušenosti $\mathrm{v}$ těchto trrídách. Přidělování odzkoušených učitelů $s$ dlouhodobou praxí do výběrové dráhy je typické i pro zahraniční vzdělávací systémy, jak upozorňují ve své studii Betts et al. (2003). Ředitel ŠO se snaží přijímat takové učitele, aby mezi nimi již rozdíl činit nemusel, a ředitel ŠD učitele ve výběrových a nevýběrových trrídách střrídá podle svého uvážení, aby přispěl ke spokojenosti učitelů.

Jednotlivé znalosti učitelů ovlivňují rozhodování vedení při jejich přidělování do tř́́d v závislosti na vizi a koncepci škol. Mezi společné rysy bychom mohli zařadit potřebu dostát zajištění kvalitního procesu výuky ve výběrových třídách přidělením učitelů $s$ dobrou znalostní základnou $\mathrm{v}$ daném oboru, $s$ mezipředmětovým přesahem, didaktickou znalostí $s$ uplatňováním odlišných metod a forem výuky a schopností přizpůsobit se náročnějšímu kurikulu výběrové tř́ídy. Všichni ředitelé se spoléhají na to, že si učitelé dokáží poradit s organizací tř́ídy a sjednáváním pořádku v ní, i když konstatují, že se chování žáků odlišuje v závislosti na typu třídy. Od všech učitelů také očekávají zájem o žáky a snahu o vytvoření funkčního kolektivu nezávisle na typu třídy. Ve všech zkoumaných školách ředitelé vnímají rozdíl mezi učiteli výběrových a nevýběrových tříd nejméně $\mathrm{v}$ jedné $\mathrm{z}$ popsaných znalostí poznatkové báze učitelství (Shulman, 1987).

Zásadní rozdíl byl zaznamenán $\mathrm{v}$ samotném očekávání vedení škol od svých učitelů. Ředitel ŠO a ředitel ŠD očekávají, že všichni jejich učitelé jsou natolik kvalitní ve své profesi, že je mohou stř́́dat mezi výběrovými a nevýběrovými tř́dami či je přidělovat do tříd zcela náhodě, podle potřeby. Oproti tomu ředitelka ŠB přiděluje učitele do výběrových či nevýběrových tříd naprosto záměrně. Výpovědi učitelů ze zkoumaných škol se shodují se závěry zahraničních studií, že žáci umístění v nevýběrové dráze dosahují horších výsledků než žáci navštěvující výběrovou dráhu (Gamoran \& Mare, 1989; Hallinan \& Kubitschek, 1999). Učitelé vnímají žáky nevýběrových tříd jako méně schopné, což ovlivňuje i jejich očekávání od nich a prrístup $\mathrm{k}$ samotné výuce. Tyto aspekty dle Finleyho (1984) přispívají k všeobecnému povědomí, že žáci nevýběrové dráhy jsou méně schopní, a proto není nutné mít na ně stejně vysoké nároky jako na žáky výběrové dráhy. Takový př́stup opět zvyšuje rozdíly mezi diferencovanými žáky a přispívá $\mathrm{k}$ navyšování vzdělanostních nerovností (Gamoran \& Bruch, 2010).

Studie ověřila, že je podstatné v rámci zjištování odpovědí na hlavní výzkumnou otázku dodržet triangulaci způsobu získá- 
vání dat (analýza dokumentů - dotazování vedení škol - dotazování učitelů - analýza srovnávacích testů). Jako př́nosný se ukázal výběr vzorku škol, vzhledem k vysokému počtu přidělovaných učitelů do tř́íd.

\section{ZÁVĚR}

Cílem výzkumného šetření bylo prozkoumat a popsat fenomén přidělování učitelů do tříd na základních školách uplatňujících diferenciaci žáků a na základě získaných dat popsat, jakým způsobem ředitelé a vedení škol přidělují učitele do trríd. Výsledky šetření dokazují, že ředitelé a vedení škol záměrně přidělují učitele do tř́íd tak, aby byl zajištěn co nejefektivnější proces vzdělávání žáků podle typu uplatňované diferenciace. Za závažné je považováno zjištění, že ředitelé, vedení a učitelé zkoumaných škol stereotypně očekávají vysoké nebo slabé výsledky žáků $v$ závislosti na typu navštěvované třídy. Toto zjištění koresponduje se šetřením DeLany (1998), který došel k obdobným výsledkům. Žáci umístění do nevýběrové dráhy jsou mnohdy znevýhodněni očekáváním učitelů, kteří na ně kladou nízké nároky, žáci proto vykazují nízké výsledky, a tím zpětně potvrzují očekávání učitelů. Jedná se o koloběh, který není dlouhodobě v diferencovaném vzdělávání řešen (Gamoran, 1993). Gamoran a Bruch (2010) také konstatujíe narůstající trend ředitelů a vedení škol rozlišujících efektivní a méně efektivní učitele prostřednictvím sledování pokroku ve výsledcích jednotlivých žáků za určitý časový úsek (obvyk- le několik let). Otázkou diskuse zůstává, do jaké míry tyto výsledky žáků vypovídají o efektivitě daného učitele $\mathrm{v}$ kontextu žákových schopností na počátku měření, jeho socioekonomického zázemí, demografické polohy školy, komunity školy a mnoha dalších souvisejících aspektů. Jedním z důvodů záměrného přidělování učitelů do tříd může být motivace dosáhnut efektivních výsledků u žáků jak výběrových, tak nevýběrových tříd přidělením optimálního učitele (Schafer \& Olexa, 1971). Dalším důvodem může být usnadnění práce učitelům, protože mnohdy je snazší vzdělávat podobně schopné žáky (Kilgore, 1991; Hallinan, 1994).

Z šetření zkoumaných škol vyplynulo, že ředitelé a vedení škol (1) přidělují kvalitnější učitele do výběrových tříd za účelem dosažení co nejlepších výsledků žáků v těchto třídách; (2) přijímají do své školy pouze takové učitele, o kterých jsou přesvědčeni, že tyto podmínky kvalitního učitele splňují, a poté již nerozlišují mezi učiteli výběrových a nevýběrových tříd, ve výběrových trúíách ale vyžadují po učitelích uplatňování prohlubujícího kurikula. Z výsledků šetření je zřejmé, že přidělování učitelů do diferencovaných tříd podporuje nerovný prýstup ke vzdělávání a zvyšuje tak rozdíly mezi žáky výběrových a nevýběrových tříd. $\mathrm{Ze}$ srovnávacích testů žáků odlišných typů tř́id na jednotlivých školách vyplynulo, že dlouhodobá diferenciace má za následek nižší dosažené výsledky u žáků nevýběrových tříd, což koresponduje i s kladením nižších nároků na ně (Hallinan \& Kubitschek, 1999; Meijnen \& Gulemond, 2002). 
Volba prŕpadové studie se ukázala vhodnou metodou pro zkoumání fenoménu, jak vedení škol přidělují učitele do tříd. Výzkumné otázky by měly dále směřovat $\mathrm{k}$ zjištění, jaká kritéria jsou pro vedení škol důležitá při přidělování učitelů do tříd, jak vnímají své přidělení učitelé a jak je tímto fenoménem ovlivňována koncepce škol, potažmo výsledky žáků různých tř́íd. Následu- jící prrípadové studie by měly poukázat na společné a odlišné rysy volby ředitelů při přidělování učitelů do tříd a poodhalit, jakým způsobem tato volba ovlivňuje podobu vzdělávání $\mathrm{v}$ různých typech trríd. Provedená studie přispívá $\mathrm{k}$ diskusi o rovném př́stupu ke vzdělávání a zachycuje pozitiva i negativa spojená s diferenciací žáků $\mathrm{v}$ českých základních školách.

\section{Literatura}

Ball, S. J. (1981). Beachside comprehensive: A case-study of secondary schooling. CUP Archive.

Betts, J., Rueben, K., \& Danenberg (2000). Selected readings on California school finance. San Francisco: Public Policy Institute of California.

Betts, J. R., \& Shkolnik, J. L. (2000). The effects of ability grouping on student achievement and resource allocation in secondary schools. Economics of Education Review, 19(1), 1-15.

Betts, J. R., Zau, A., \& Rice, L. (2003). Determinants of student achievement: New evidence from San Diego. San Francisco, CA: Public Policy Institute of California.

Burgess, R. G. (1983). Experiencing comprehensive education: A study of Bishop McGregor School. London: Taylor \& Francis.

Carey, N. (1994). Curricular differentiation in public high schools. Fast response survey system. E.D. Tabs. Washington, DC: US Government Printing Office.

Clotfelter, C. T., Ladd, H. F., \& Vigdor, J. L. (2006). Teacher-student matching and the assessment of teacher effectiveness. Journal of Human Resources, 41(4), 778-820.

Cohen, D. K., Raudenbush, S. W., \& Ball, D. L. (2003). Resources, instruction, and research. Educational Evaluation and Policy Analysis, 25(2), 119-142.

DeLany, B. (1998). The micro-politics of school, teacher, and student failure: Managing turbulence. In B. Franklin (Ed.), When children don't learn: Student failure and the culture of teaching (s. 134-159). New York: Columbia University.

Donaldson, M. L., \& Johnson, S. M. (2011). Teach for America teachers: How long do they teach? Why do they leave?. Phi Delta Kappan, 93(2), 47-51.

Dupriez, V., Dumay, X., \& Vause, A. (2008). How do school systems manage pupils' heterogeneity?. Comparative Education Review, 52(2), 245-273.

Dvořáková, M., \& Tvrzová, I. (2010). Proměna současné školy z hlediska učitele. In H. Krykorková \& R. Váňová (Eds.), Učitel v současné škole (s. 281-302). Praha: Filozofická fakulta Univerzity Karlovy

Evertson, C. M. (1982). Differences in instructional activities in higher- and lower-achieving junior high English and math classes. The Elementary School Journal, 82(4), 329-350. 
Feng, L. (2010). Hire today, gone tomorrow: New teacher classroom assignments and teacher mobility. Education Finance and Policy, 5(3), 278-316.

Finley, M. K. (1984). Teachers and tracking in a comprehensive high school. Sociology of Education, 57(4), 233-243.

Gamoran, A. (1992). Synthesis of research: Is ability grouping equitable?. Educational Leadership, $50(1), 11-11$.

Gamoran, A., \& Mare, R. D. (1989). Secondary school tracking and educational inequality: Compensation, reinforcement, or neutrality?. American journal of Sociology, 94(5), $1146-1183$.

Gaziel, H. H. (1997). Impact of school culture on effectiveness of secondary schools with disadvantaged students. The Journal of Educational Research, 90(5), 310-318.

Goodlad, J. I. (1984). A place called school. Prospects for the future. New York: McGraw-Hill.

Gamoran, A., \& Bruch, S. (2010). Alternative models for human capital development in education research. Report to the Spencer Foundation. (Online). Dostupné z www.spencer.org

Glaser, B. G., \& Strauss, A. L. (1967). The discovery of grounded theory: Strategies for qualitative research. Chicago: Aldire.

Goe, L. (2007). The link between teacher quality and student outcomes: A research synthesis. Washington, DC: National Comprehensive Center for Teacher Quality.

Goldhaber, D., Perry, D., \& Anthony, E. (2004). The National Board for Professional Teaching Standards (NBPTS) process: Who applies and what factors are associated with NBPTS certification?. Educational Evaluation and Policy Analysis, 26(4), 259-280.

Greger, D. (2004). Koncept spravedlivosti a diferenciace žáků. In E. Walterová et al., Úloha školy v rozvoji vzdèlanosti (s. 362-370).

Greger, D. (2006). Vzdělanostní nerovnosti v teoretické reflexi. In P. Matějů, J. Straková et al., Nerovné śance na vzdèláni: Vzdělanostni nerovnosti v České republice (s. 00-00). Praha: Academia.

Greger, D., Chvál, M., Walterová, E., \& Černý, K. (2009). Názory českých rodičů a veřejnosti na časné rozdělování žáků. Orbis scholae, 3(3), 51-78.

Hallinan, M. T. (1994). Tracking: From theory to practice. Sociology of Education, 67(2), $79-84$.

Hallinan, M. T., \& Kubitschek, W. N. (1999). Curriculum differentiation and high school achievement. Social Psychology of Education, 3(1-2), 41-62.

Hanushek, E. A., Kain, J. F., O‘Brien, D. M., \& Rivkin, S. G. (2005). The market for teacher quality (No. w11154). National Bureau of Economic Research.

Haycock, K. (1998). Good teaching matters: How well-qualified teachers can close the gap. Thinking k-16, 3(2), n2.

Heck, R. H., \& Marcoulides, G. A. (1990). Examining contextual differences in the development of instructional leadership and school achievement. The Urban Review, 22(4), $247-265$. 
Howie, S. J., Combrinck, C., Roux, K., Tshele, M., Mokoena, G., \& McLeod Palane, N. (2017). PIRLS Literacy 2016: Progress in International Reading Literacy Study (PIRLS) 2016: South African children's reading literacy achievement. Centre for Evaluation and Assessment (CEA).

Ireson, J., Clark, H., \& Hallam, S. (2002). Constructing ability groups in the secondary school: Issues in practice. School Leadership \& Management, 22(2), 163-176.

Janík, T. (2004). Význam Shulmanovy teorie pedagogických znalostí pro oborové didaktiky a pro vzdělávání učitelů. Pedagogika, 54(3), 243-250.

Janík, T., \& Slavík, J. (2007). Vztah obor - vyučovací předmět jako metodologický problém. Orbis scholae, 2(1), 54-66.

Kadrnožková, M. (2019). Jak vedeni výbérových základnich škol priděluje učitele do tríd? (Diserační práce).

Kilgore, S. B. (1991). The organizational context of tracking in schools. American Sociological Review, 56(2), 189-203.

Kulik, C. L. C., \& Kulik, J. A. (1982). Effects of ability grouping on secondary school students: A meta-analysis of evaluation findings. American Educational Research Journal, 19(3), 415-428.

Kunter, M., Klusmann, U., Baumert, J., Richter, D., Voss, T., \& Hachfeld, A. (2013). Professional competence of teachers: Effects on instructional quality and student development. Journal of Educational Psychology, 105(3), 805-820.

Lankford, H., Loeb, S., \& Wyckoff, J. (2002). Teacher sorting and the plight of urban schools: A descriptive analysis. Educational Evaluation and Policy Analysis, 24(1), 37-62.

Leix, A. (2006). Transkripce nahrávek v kontextu etickém, metodologickém a technickém. (Disertační práce). Brno: Masarykova univerzita.

Loeb, S., Kalogrides, D., \& Béteille, T. (2012). Effective schools: Teacher hiring, assignment, development, and retention. Education Finance and Policy, 7(3), 269-304.

Mareš, J. (2007). Sociálni klima školy jako teoretický a výzkumný problém. (Disertační práce). Masarykova univerzita, Fakulta sociálních studií.

Matějů, P., \& Straková, J. (2003). Role rodiny a školy v reprodukci vzdělanostních nerovností. Sociologický pohled na úlohu víceletých gymnázií ve světle výzkumu PISA 2000. Sociologický Casopis / Czech Sociological Review, 39(5), 625-652.

Maxwell, J. A. (2008). Designing a qualitative study. In L. Bickman \& D. J. Rog (Eds.), The SAGE handbook of applied social research methods (s. 214-253). 2. vyd. Thousand Oaks, CA: Sage.

Meijnen, G. W., \& Guldemond, H. (2002). Grouping in primary schools and reference processes. Educational Research and Evaluation, 8(3), 229-248.

Miovský, M. (2006). Kvalitativni prístup a metody v psychologickém výzkumu. Praha: Grada.

Mullis, I. V. S., Martin, M. O., Foy, P., \& Hooper, M. (2016). TIMSS advanced 2015 international results in advanced mathematics and physics. Boston: Boston College, TIMSS \& PIRLS International Study Center. 
Murphy, J., \& Hallinger, P. (1989). Equity as access to learning: Curricular and instructional treatment differences. Journal of Curriculum Studies, 21(2), 129-149.

Nystrand, M., \& Gamoran, A. (1990). Student engagement: When recitation becomes conversation. Madison, WI: University of Wisconsin.

Oakes, J. (1986). Keeping track, part 2: Curriculum inequality and school reform. The Phi Delta Kappan, 68(2), 148-154.

Oakes, J., Wells, A. S., \& Jones, M. (1997). Detracking: The social construction of ability, cultural politics, and resistance to. Teachers College Record, 98(3), 482-510.

OECD. (2016). PISA 2015 results (Volume I): Excellence and equity in education.

O'Sullivan, B. (1999). Global change and educational reform in Ontario and Canada. Canadian Journal of Education / Revue canadienne de l'education, 24(3), 311-325.

Page, R. N. (1991). Lower-track classrooms: A curricular and cultural perspective. New York: Teachers College Press.

Palán, Z. (2006). Celoživotni učeni. Vybrané problémy vzdělávací politiky. Praha: Karolinum.

Patton, M. Q. (1990). Qualitative evaluation and research methods. Thousand Oakes: Sage.

Patton, M. Q. (2002). Two decades of developments in qualitative inquiry: A personal, experiential perspective. Qualitative social work, 1(3), 261-283.

Rosenbaum, J. E. (1976). Making inequality: The hidden curriculum of high school tracking. New York: Wiley.

Scafidi, B., Sjoquist, D. L., \& Stinebrickner, T. R. (2007). Race, poverty, and teacher mobility. Economics of Education Review, 26(2), 145-159.

Schafer, W. E., \& Olexa, C. (1971). Tracking and opportunity: The locking-out process and beyond. Scranton, PA: Chandler.

Schwartz, F. (1981). Supporting or subverting learning: Peer group patterns in four tracked schools. Anthropology \& Education Quarterly, 12(2), 99-121.

Shulman, L. S. (1986). Those who understand: Knowledge growth in teaching. Educational Researcher, 15(2), 4-14.

Shulman, L. (1987). Knowledge and teaching: Foundations of the new reform. Harvard Educational Review, 57(1), 1-23.

Spilková, V. (2002). Koncept kvalitní, dobré školy: model a možnosti jeho zkoumání ve školní praxi. In J. Vašutová \& V. Spilková, Rozvoj národni vzdělanosti a vzděláváni učitelì $v$ evropském kontextu II. Metody a výsledky empirických výzkumů (s. 24-39). Praha: Pedagogická fakulta UK.

Stake, R. E. (2005). Qualitative case studies. In N. K. Denzin \& Y. S. Lincoln (Eds.), The Sage handbook of qualitative research (s. 443-466). Thousand Oaks, CA: Sage.

Straková, J., \& Greger, D. (2013). Faktory ovlivňující přechod žáků 5. ročníků na osmileté gymnázium. Orbis scholae, 7(3), 73-85.

Šed’ová, K. (2005). Možnosti uplatnění zakotvené teorie v pedagogickém výzkumu: Rodinná socializace dětského televizního diváctví. Studia paedagogica, 53(10), 123-132. 
Švaříček, R. \& Šedová, K. et al. (2007). Kvalitativní výzkum v pedagogických védách. Praha: Portál. Švec, Š. (1998). Metodológia vied o výchove. Bratislava: IRIS.

Vališová, A., \& Kasíková, H. (2007). Pedagogika pro učitele. Praha: Grada.

Van Houtte, M. (2006). School type and academic culture: evidence for the differentiationpolarization theory. Journal of Curriculum Studies, 38(3), 273-292.

Vašutová, J. (2001). Kvalifikační předpoklady pro nové role učitelů. In E. Walterová (Ed.), Učitelé jako profesni skupina, jejich vzděláváni a podpuirný systém 1 (s. 19-46). Praha: Pedagogická fakulta UK.

Yin, R. K. (2014). Case study research: Design and methods. 5. vyd. Thousand Oaks, CA:Sage.

PhDr. Monika Kadrnožková, Ph.D.

Pedagogická fakulta Univerzity Karlovy, Ústav výzkumu a rozvoje vzdèláváni;

e-mail: monika.kadrnozkova@pedf.cuni.cz

\section{KADRNOŽKOVÁ, M. How Does the School Management Assign Teachers to Classes at Selective Elementary Schools?}

The Czech education system allows pupils to be assigned to schools and classes on the basis of their ability and achievements. There is currently a trend of increasing numbers of primary schools applying long-term selection of pupils within the school. The topic of teacher allocation is also closely linked to the distribution of pupils into different types of classes.

This text aims to verify whether the management of the three selective schools deliberately assigns teachers to classes and what criteria affect them. A descriptive case study and anchored theories were identified as a research strategy to meet this goal. The data collection methods that were chosen included analysis of teacher allocation to classrooms in relevant documents (SVP, schedules, annual reports), in-depth semi-structured interviews with school management and teachers, and analysis of the results of comparative tests of pupils within schools. The results show that management follows different criteria in their choice, justifying efforts to educate the pupils of the selection pathway as effectively as possible. Teachers are assigned to classes on the basis of a leadership choice that is based on the quality teacher's own criteria - the selection classes are assigned to "better-quality" teachers, or it is an effort by management to recruit only such teachers so that they no longer have to choose and can assign teachers to classes in an "alternate" or "random" way. But in each of the cases, the leadership's effort was to live up to a deeper curriculum in the selection class, with more demanding content and thoughtful didactic methods. The selected schools have become an interesting example of teacher allocation to classes, which affects not only the teaching process but also the results of the pupils themselves.

Keywords: teacher allocation, pupil differentiation, principal choice, primary school, case study. 